\title{
Short communication: Effect of dry therapy using an intramammary infusion on bulk tank somatic cell count in sheep
}

\author{
C. Gonzalo, ${ }^{11}$ B. Linage, ${ }^{*}$ J. A. Carriedo, ${ }^{*}$ M. T. Juárez,† E. Beneitez,† A. Martínez,† and L. F. De La Fuente* \\ *Departamento de Producción Animal, Facultad de Veterinaria, Universidad de León, 24071-León, Spain \\ †Consorcio de Promoción del Ovino, Camino de Canillas s/n, 49630-Villalpando, Zamora, Spain
}

\begin{abstract}
A total of 3,141 records of bulk tank milk somatic cell counts (BTSCC) and bulk tank milk total bacterial counts (BTTBC) were obtained over 24 mo from 25 dairy flocks of Assaf ewes belonging to the Consortium for Ovine Promotion in Castilla-León, Spain, in which a complete dry therapy program was carried out in 10,313 ewes using an antibiotic infusion containing 100 $\mathrm{mg}$ of penethamate hydriodide, $280 \mathrm{mg}$ of benethamine penicillin, and $100 \mathrm{mg}$ of framycetin sulfate. The selection criteria for all flocks were BTSCC mean values $\geq 1,000 \times 10^{3}$ cells $/ \mathrm{mL}$ and absence of dry therapy before the start of this experiment. Significant effects on $\log$ BTSCC were detected for treatment, milking system, flock within milking system, month within flock by treatment, the interactions treatment by milking system and flock by treatment within milking system, and $\log$ BTTBC. After dry therapy was implemented, $\log$ BTSCC decreased significantly in machine-milked flocks $(5.95 \pm 0.007)$ compared with values before antibiotic treatment $(6.13 \pm 0.008)$. The effect was observed at the beginning of the second lactation posttreatment $(5.98 \pm 0.013)$. However, dry therapy was not effective in hand-milked flocks, suggesting poor hygiene conditions. A significant relationship was found between BTSCC and BTTBC; therefore, programs for improving milk hygiene should be implemented for both BTSCC and BTTBC variables at the same time.
\end{abstract}

Key words: antibiotic dry therapy, milking type, somatic cell count, dairy flock

In the European Union (EU) very few intramammary antibiotic formulations are registered for use in dairy sheep mastitis (Marco, 1994; Bergonier and Berthelot, 2003; Contreras et al., 2005) and an attempt should be made to evaluate the effectiveness of other antibiotic combinations within the mastitis control programs. In previous studies (Linage and Gonzalo, 2006; 2008),

Received May 29, 2008.

Accepted September 12, 2008.

${ }^{1}$ Corresponding author: c.gonzalo@unileon.es the use of a antibiotic infusion at drying-off combining penethamate hydriodide, benethamine penicillin, and framycetin sulfate significantly decreased IMI prevalence and SCC during the dry period in dairy ewes, because of greater IMI cure rates and lower reinfection and new-infection rates in treated ewes compared with nontreated ones. In addition, milk antibiotic residues were not detected in dry treated ewes over $54 \mathrm{~h}$ postpartum using the blue-yellow screening test adapted to ovine milk (Linage et al., 2007); the detection limits for 3 to $4 \mu \mathrm{g} / \mathrm{kg}$ for penicillin and 704 to $781 \mu \mathrm{g} / \mathrm{kg}$ for framycetin were lower than maximum residue limits established by the EU in ovine milk (4 and 1,500 $\mu \mathrm{g} /$ $\mathrm{kg}$, respectively). But the effect of this treatment in commercial ewe dairy flocks on bulk tank milk SCC (BTSCC) under field conditions has not been documented. Bulk tank SCC was the first and principal tool used by technicians and farmers to evaluate and monitor udder health in dairy flocks (Jayarao and Wolfgang, 2003; Gonzalo et al., 2005). The EU has yet to regulate BTSCC in ewe milk used for dairy products sold in its region. Studies need to be carried out to identify the main sources of variations in BTSCC (i.e., dry therapy, DT) in the primary dairy sheep areas of the EU. The objective of the present study was to determinate the effect of an antibiotic combination containing penethamate hydriodide, benethamine penicillin, and framycetin sulfate used as DT on the BTSCC variation in 25 commercial dairy sheep flocks.

A total of 3,141 records for BTSCC and bulk tank milk total bacterial count (BTTBC) were obtained for 2 complete years from Assaf ewes (23 flocks with machine milking and 2 with hand milking) belonging to the Consortium for Ovine Promotion (CPO) in Castilla-León, Spain. The Castilla-León region has about 1.5 million milking ewes; the flock characteristic features of this area are described elsewhere (Gonzalo et al., 2005). Briefly, average flock size was about 400 ewes, and each flock was generally divided into 2 groups, in which the lambing period alternated every 6 mo. All CPO flocks were enrolled in the Analysis Service of the Dairy Interprofessional Laboratory of Castilla-León. Throughout the $24 \mathrm{mo}$ of the experiment, an average of 5.2 repeated 
Table 1. Least squares means of $\log$ SCC (LSM), SE, and SCC geometric means $\left(\times 10^{3}\right.$ cells $/ \mathrm{mL}$; GM) by treatment in each milking system and overall

\begin{tabular}{lccc}
\hline & \multicolumn{3}{c}{ Period } \\
\cline { 2 - 4 } Milking system & Pretreatment $(9$ mo $)$ & Treatment $(12$ mo $)$ & Posttreatment $(3$ mo $)$ \\
\hline Overall & & & \\
$n^{1}$ & 1,096 & 1,645 & 400 \\
LSM & $6.24^{\mathrm{a}}$ & $6.15^{\mathrm{b}}$ & $6.16^{\mathrm{b}}$ \\
SE & 0.014 & 0.012 & 0.027 \\
GM & 1,725 & 1,422 & 1,458 \\
Hand milking & & & 28 \\
n & 90 & 143 & $6.34^{\mathrm{a}}$ \\
LSM & $6.35^{\mathrm{a}}$ & $6.35^{\mathrm{a}}$ & 0.053 \\
SE & 0.027 & 0.023 & 2,201 \\
GM & 2,216 & 2,245 & 372 \\
Machine milking & & 1,502 & $5.98^{\mathrm{c}}$ \\
n & 1,006 & $5.95^{\mathrm{b}}$ & 0.013 \\
LSM & $6.13^{\mathrm{a}}$ & 0.007 & 965 \\
SE & 0.008 & 901 & \\
GM & 1,344 & & \\
\hline
\end{tabular}

${ }^{\mathrm{a}-\mathrm{c}}$ Means in the same row with different superscripts differ $(P<0.05)$.

${ }^{1}$ Number of observations.

bulk tank milk observations were carried out per month in each flock. The 25 flocks selected had BTSCC mean values $\geq 1,000 \times 10^{3}$ cells $/ \mathrm{mL}$, and $\mathrm{DT}$ had not been used in any flocks before the start of this experiment. In each flock, the presence of Mycoplasma agalactiae was examined in the BT milk samples every 4 mo over $2 \mathrm{yr}$ following the procedure described by Gonzalo et al. (2002). Studies of antibiotic sensitivity were performed to avoid the treatment of flocks infected with mammary pathogens that could be resistant to antibiotic treatment.

All ewes of both groups in all flocks were treated at drying-off with the same antibiotic combination. The intramammary infusion used as DT contained $100 \mathrm{mg}$ of penethamate hydriodide, $280 \mathrm{mg}$ of benethamine penicillin, and $100 \mathrm{mg}$ of framycetin sulfate (Mamyzin secado, Benestermycin, Boehringer Ingelheim, Barcelona, Spain). A single treatment per half-udder (1 syringe per teat) was performed. The total number of ewes treated was 10,313 . Farmers received veterinary protocols for milking hygiene and management (milking routines and postmilking teat disinfection). Although in previous studies (Linage and Gonzalo, 2006, 2008) antibiotic residues were not detected $\geq 54 \mathrm{~h}$ postpartum, in the present experiment the withdrawal time after lambing was $7 \mathrm{~d}$ (Directive 2001/82/EC, amended by Directive 2004/28/EC).

Before DT, BTSCC records were obtained for 9 mo with the objective to define the health and hygienic situation of all flocks before DT. This was defined as the pretreatment period. The BTSCC variation after DT was studied throughout the 12 mo corresponding to subsequent and consecutive lactations in both ewe groups (6 mo/group). This was defined as the treatment period. In addition, BTSCC records for the 3 mo at the beginning of the second lactation after DT were included; this period was defined as posttreatment.

Somatic cell count was determined using a Fossomatic 5000 (Foss Electric, Hillerød, Denmark), and BTTBC was determined by a Bactoscan 8000 (Foss Electric), both periodically checked by the reference methods (IDF, 1991, 1995). Total bacterial count records were obtained and included in the statistical analyses because of the relationship with BTSCC in dairy sheep (Gonzalo et al., 2006).

A mixed model with repeated observations, in which the month within flock $\times$ treatment interaction was a random factor, was used to study BTSCC variation. The PROC MIXED procedure (SAS Institute, 1998) was followed according to the model below:

$$
\begin{aligned}
& Y_{i j k l m}=\mu+T_{i}+M_{j}+F_{k(j)}+T_{i j} \\
& +\mathrm{TF}_{\mathrm{ik}(\mathrm{j})}+\mathrm{O}_{1(\mathrm{ijk})}+\mathrm{bX}_{\mathrm{ijklm}}+\mathrm{e}_{\mathrm{ijklm}},
\end{aligned}
$$

where $Y_{i j k l m}$ was the logarithm of BTSCC, $\mu$ was the mean, $\mathrm{T}_{\mathrm{i}}$ was the treatment effect (3 levels: pretreatment, corresponding to first 9 mo before DT; treatment, corresponding to 12 mo in which DT effect was studied; and posttreatment, corresponding to initial 3 mo of second lactation after DT); $\mathrm{M}_{\mathrm{j}}$ was the milking system (hand and machine milking); $\mathrm{F}_{\mathrm{k}(\mathrm{j})}$ was the effect of flock within milking system; $\mathrm{TM}_{\mathrm{ij}}$ was the treatment $\times$ milking system interaction; $\mathrm{TF}_{\mathrm{ik}(\mathrm{j})}$ was the treatment $\times$ flock interaction within milking system; $\mathrm{O}_{1(\mathrm{ijk})}$ was the random effect of month within flock $\times$ treatment; $b$ was 
the slope of regression between BTSCC and BTTBC; and $\mathrm{e}_{\mathrm{ijk} k \mathrm{~m}}$ was the residual effect.

Dry therapy had an important effect on BTSCC (Table $1)$. This treatment significantly decreased $(P<0.001)$ BTSCC (log BTSCC: 6.15 , and geometric mean: 1,422 $\times 10^{3}$ cells $/ \mathrm{mL}$ ) in the subsequent lactation compared with pretreatment lactations (log BTSCC: 6.24 and geometric mean: $1,725 \times 10^{3}$ cells $/ \mathrm{mL}$ ). The beginning of second lactation posttreatment (log BTSCC: 6.16 , and geometric mean: $1,458 \times 10^{3}$ cells $/ \mathrm{mL}$ ) also showed significantly lower BTSCC values than did pretreated lactations. Dry therapy was generally associated with improved milking hygiene in subsequent lactations, so this practice was efficient in reducing IMI prevalence and improving milk quality. These results were compatible with those obtained in an experimental study on half-udder SCC variation in ewes treated at drying-off with the same antibiotic infusion (Linage and Gonzalo, 2008).

Milking system was a significant factor $(P<0.001)$ in explaining the variation in BTSCC. Mean of log BTSCC $( \pm \mathrm{SE})$ was $6.35 \pm 0.021$ for hand-milked flocks (geometric mean: $2,221 \times 10^{3}$ cells $/ \mathrm{mL}$ ) and $6.02 \pm$ 0.006 for machine-milked flocks (geometric mean: 1,053 $\times 10^{3}$ cells $/ \mathrm{mL}$ ). These results were in agreement with those obtained by other authors (Gonzalo et al., 2005) in dairy ewe flocks in the same geographical area. Flock within milking system effect contributed significantly to variation of BTSCC $(P<0.001)$. This was probably because of differences in management and hygiene practice in herds, which would result in considerable differences in the prevalence of mammary infection and BTSCC, according to Gonzalo et al. (2005).

Interaction treatment by milking type was significant $(P<0.001)$ and showed differences in BTSCC between machine- and hand-milked flocks (Table 1). Dry therapy was not effective in decreasing BTSCC in hand-milked flocks, probably because of poor hygiene conditions associated with hand milking. The treatment effect was very important in 23 machine-milked flocks. Thus, log BTSCC was significantly lower in the treatment period (5.95) than in the pretreatment period (6.13). Log BTSCC value for the posttreatment period was 5.98 in machine-milked flocks, which was higher than during the treatment period, indicating that BTSCC increased when DT was not repeated. In addition, a significant interaction of flock $\times$ treatment within milking system $(P<0.001)$ was found. Thus, the DT effect was not uniform in all flocks.

The BTTBC covariable contributed significantly to variation of BTSCC. Percentage of residual variance $(18.9 \%)$ was relatively small, showing the relative suitability of the mathematical model used to study BTSCC. Month was an important factor of variation, as it explained $18.5 \%$ of total variance; we have previously discussed the biological significance of this factor (Gonzalo et al., 2005). Mycoplasma agalactiae was not isolated from bulk tank milk.

Parameter $\mathrm{b}( \pm \mathrm{SE})$ of the regression of $\log \mathrm{BTTBC}$ on $\log$ BTSCC in the model was $0.034 \pm 0.009(P<$ 0.001 ), and the correlation coefficient between these variables was $\mathrm{r}=0.13(P<0.001)$, indicating that high BTTBC is associated with high BTSCC. This is in accordance with the results in dairy sheep from other researchers (Gonzalo et al., 2006). Therefore, the implementation of programs for improving hygiene and health quality in bulk tank milk would be more efficient if both variables were considered. In this sense, dairy sheep flocks have inferior hygienic conditions (i.e., high number of animals, absence of teat-washing practices before milking) than dairy cattle herds, and this can be relevant to DT effectiveness. In commercial machinemilked flocks studied, BTSCC decreased $>30 \%$ after DT compared with the pretreatment situation; thus, both the repetition of DT in subsequent lactations and the improvement in hygiene practices could be more efficient in reducing IMI prevalence and improving milk quality.

The antibiotic combination evaluated as dry ewe therapy was very efficient in reducing milk SCC in the subsequent lactation in commercial machine-milked flocks in which hygiene conditions were improved compared with hand-milked flocks.

\section{ACKNOWLEDGMENTS}

This paper was developed within the Plan Nacional I+D+i: project PETRI 95-0839.OP between the University of León (León, Spain) and the Consortium for Ovine Promotion (CPO) in Castilla-León, Villalpando, Zamora, Spain. The authors thank Boehringer Ingelheim Spain S.A. for their cooperation.

\section{REFERENCES}

Bergonier, D., and X. Berthelot. 2003. New advances in epizootiology and control of ewe mastitis. Livest. Prod. Sci. 79:1-16.

Contreras, A., A. Sánchez, J. C. Corrales, D. Sierra, C. Gonzalo, and M. J. Paape. 2005. Mastitis in small ruminants. Pages 67-74 in Mastistis in Dairy Production. H. Hogeveen, ed. Wageningen Academic Publishers, Wageningen, the Netherlands.

Gonzalo, C., A. Ariznabarreta, J. A. Carriedo, and F. San Primitivo. 2002. Mammary pathogens and their relationship with somatic cell count and milk yield losses in dairy ewes. J. Dairy Sci. 85:14601467.

Gonzalo, C., J. A. Carriedo, E. Beneitez, M. T. Juárez, L. F. De La Fuente, and F. San Primitivo. 2006. Bulk tank total bacterial count in dairy sheep: factors of variation and relationship with somatic cell count. J. Dairy Sci. 89:549-552.

Gonzalo, C., J. A. Carriedo, M. A. Blanco, E. Beneitez, M. T. Juárez, L. F. De La Fuente, and F. San Primitivo. 2005. Factors of variation 
influencing bulk tank milk somatic cell count in dairy sheep. J. Dairy Sci. 88:969-974.

International Dairy Federation. 1991. Enumeration of microorganisms. IDF standard 100B. International Dairy Federation, Brussels, Belgium.

International Dairy Federation. 1995. Enumeration of somatic cells. IDF standard 148A. International Dairy Federation, Brussels, Belgium.

Jayarao, B. M., and D. R. Wolfgang. 2003. Bulk-tank milk analysis. A useful tool for improving milk quality and flock udder health. Vet. Clin. North Am. Food Anim. Pract. 19:75-92.

Linage, B., and C. Gonzalo. 2006. Residuos antibióticos en el periodo postparto tras terapias de secado en el ovino lechero. Pages 291293 in Actas XXI Jornadas SEOC, 2006, Zamora.
Linage, B., and C. Gonzalo. 2008. Influence of an intramammary infusion at drying-off of combined penethamate hydriodide, benethamine penicillin and framycetin sulfate on intramammary infections and somatic cell counts in dairy sheep. J. Dairy Sci. 91:3459-3466.

Linage, B., C. Gonzalo, J. A. Carriedo, J. A. Asensio, M. A. Blanco, L. F. De La Fuente, and F. San Primitivo. 2007. Performance of blue-yellow screening test for antimicrobial detection in ovine milk. J. Dairy Sci. 90:5374-5379.

Marco, J. C. 1994. Mastitis en la oveja Latxa: Epidemiología, diagnóstico y control. Doctoral thesis. Univ. Zaragoza, Spain.

SAS Institute. 1998. SAS User's Guide. SAS Institute Inc., Cary, NC. 